\title{
Mechanisms of Immune Injury in Rheumatoid Arthritis: Evidence for the Involvement of T Cells and Heat-Shock Protein
}

\author{
SAMUEl STROBER* \& JOSEPH HOLOShITZ**
}

\section{INTRODUCTION}

Rheumatoid arthritis (RA) is a chronic inflammatory disorder affecting multiple organs, as well as the joints. The inflammatory process in the joints involves the synovium which is normally a single cell membrane covering the inner aspect of the joint cavity. In RA and other inflammatory joint diseases, the synovium becomes markedly thickened due to synovial cell proliferation and infiltration by inflammatory cells. The inflamed tissue (pannus) expands into the joint cavity, erodes cartilage and bone, and eventually leads to destruction of joints (Harris et al. 1990).

Neither the etiology nor the pathogenesis of RA are known. The relative contributions of cell-mediated and humoral immunity to joint inflammation and destruction in RA are poorly understood. Autoantibodies, exemplified by rheumatoid factors (RFs), have been identified in the serum and synovial fluid (SF) of patients with active joint disease (Zvaifler 1973). Indeed, the synovial membrane appears to be the principal site of synthesis of RF (Sliwinski \& Zvaifler 1970, Smily et al. 1968, Wernick et al. 1985), and within the synovial fluid RF-containing immune complexes may play a critical part in joint inflammation by the activation of complement (Munthe \& Natvig 1971, Sabharwal et al. 1982). Complement breakdown products are known to be able to stimulate

*Standford University School of Medicine, Department of Medicine, Division of Immunology and Rheumatology, Rm. S-105 B, Stanford, CA 94305; **University of Michigan School of Medicine, Department of Medicine, Division of Rheumatology, Ann Arbor, MI 49109-0531, U.S.A. 
the influx of neutrophils in the joint and to increase vascular permeability at this site (Ward \& Zvaifler 1971).

Against this background, there is also increasing evidence for a role for $\mathrm{T}$ cell-mediated immune responses in the pathogenesis of RA. Firstly, the influence of major histocompatibility genes in disease susceptibility may be taken as evidence for a central role of a T cell-mediated response (Stastny et al. 1983). Secondly, immunohistological examination of the synovium in RA has shown a prominent infiltrate of lymphocytes; the majority of these are $\mathrm{T}$ cells which appear to be activated (Duke et al. 1982, Klareskog et al. 1982, Young et al. 1984, Malone et al. 1984). Thirdly, several therapies whose principal action appears confined to $\mathrm{T}$ lymphocytes have been reported to be effective in RA; these include thoracic duct drainage (Paulus et al. 1977), cyclosporine A (Weinblatt et al. 1986), and total lymphoid irradiation (Kotzin et al. 1981, Trentham et al. 1981, Strober et al. 1985, Field et al. 1983). However, it is not clear whether synovial $\mathrm{T}$ lymphocytes are responding to an antigenic stimulus within the joint, or whether they infiltrate the synovium as a consequence of the inflammatory process already active at this site. In either case, $\mathrm{T}$ cells could contribute to inflammation either directly (e.g., by cytotoxicity towards synoviocytes) or by the release of lymphokines.

In adjuvant arthritis, a model of autoimmune arthritis in rats, T-cell clones have been isolated that can transfer arthritis to syngeneic rats (Holoshitz et al. 1983 , 1984). In both adjuvant arthritis and RA, reactivity of T cells to mycobacterial antigens has been implicated in the pathogenesis of joint inflammation. In adjuvant arthritis, the epitope recognized by the disease-inducing T-cell clones has been found on the $65 \mathrm{Kd}$ heat-shock protein (HSP) of mycobacteria (Van Eden et al. 1988). In RA, both fresh synovial fluid T cells and synovial Tcell clones have been found to proliferate in response to the acetone precipitable fraction of mycobacterium tuberculosis (AP-MT) or to the purified $65 \mathrm{Kd}$ heat-shock protein (Holoshitz et al. 1986, Res et al. 1988).

In the following sections, the evidence obtained in our previous and current studies for the involvement of $\mathrm{T}$ cells and heat-shock proteins in the immune injury to joint tissues in RA will be reviewed in detail.

Improvement in rheumatoid arthritis after total lymphoid irradiation (TLI) is associated with depletion of $\mathrm{CD4}^{+} \mathrm{T}$ cells

Total lymphoid irradiation, a radiotherapy regimen primarily used to treat Hodgkin's disease, induces a long-lasting suppression of immune responses regulated by T cells in humans and laboratory animals (Fuks et al. 1976, Strober et al. 1979). Studies of the efficacy of TLI in the treatment of established autoimmune disease in laboratory animals showed that this radiotherapy regimen produced long-term remissions in adjuvant arthritis in rats (Schurman et 
al. 1981), in the lupus-like disease of NZB/NZW and MRL/1 mice (Kotzin \& Strober 1979, Theofilopoulos et al. 1980) and in the accelerated form of autologous-induced nephritis in rats (Lowry et al. 1984). Total lymphoid irradiation has also been used to induce tolerance to tissue transplants in both small inbred and large outbred laboratory animals (Strober et al. 1979, 1984, Waer et al. 1984), and to prevent rejection of cadaver renal transplants in humans (Najarian et al. 1982, Waer et al. 1987).

To determine the efficacy of TLI in a controlled trial, a double-blind, randomized study was done using patients with intractable rheumatoid arthritis for whom conventional therapy (non-steroid anti-inflammatory drugs, gold compounds, and penicillamine) had failed, and who ordinarily would have been candidates for treatment with cytotoxic drugs. The patients were given a full immunosuppressive dose of TLI (2000 rad), or a low dose (200 rad) which produced no detectable immune suppression.

Disease activity in the high-dose group was significantly improved as judged by the change in the mean scores for all four variables used in the study (morning stiffness, joint tenderness score, joint swelling score, and functional impairment score) at both 3 and 6 months after TLI (Table I). No significant change was seen in any of these variables at 3 and 6 months in the low-dose group. A comparison of the percent improvement in each variable showed that the high-dose group improved significantly as compared to the low-dose group in morning stiffness, functional impairment and joint tenderness scores. Although the joint swelling score in the high-dose group improved significantly as compared to pretreatment values, the improvement was not significant as compared to that of the low-dose group.

An arbitrary definition of a response to treatment can be made using an improvement of at least $25 \%$ in three of four variables. Using the latter definition, and 9 of 12 high-dose and 3 of 11 low-dose patients responded at 6 months. The differences in the fraction of responders in both groups is significant using the chi-square test. These results provide evidence that TLI is effective in the treatment of patients with RA for whom treatment with both gold compounds and penicillamine had previously failed. Analysis of the responses of women and men in the high-dose group of the current study or in the previous uncontrolled studies (Kotzin et al. 1981, Field et al. 1983) showed no trend to suggest a different response rate between the two sexes.

A significant reduction in the in vitro peripheral blood mononuclear cell proliferative response to mitogens (phytohemagglutinin and concanavalin A) and antigens (herpes zoster, tetanus toxoid, and allogeneic leukocytes) was seen after high-dose TLI (Fig. 1). This reduction was associated with a marked lymphopenia primarily due to the reduction in the number of helper/inducer $\mathrm{T}$ cells (CD4 ${ }^{+}$cells) (Fig. 2). The mean ratio of suppressor/cytotoxic $\mathrm{T}$ cells $\left(\mathrm{CD} 8^{+}\right.$cells) to helper $\mathrm{T}$ cells rose from 0.72 to 1.95 after high-dose TLI. Our 
TABLE I

Changes in the joint disease activity measurements before and after high-dose or low-dose total lymphoid irradiation*

\begin{tabular}{lccc}
\hline & Before & After (6 months) & p Value** \\
\hline $\begin{array}{l}\text { Morning stiffness (hours) } \\
\text { High dose }\end{array}$ & $6.5 \pm 1.3$ & $2.3 \pm 1.0$ & $<0.02$ \\
$\quad$ Low dose & $4.7 \pm 1.2$ & $4.7 \pm 1.4$ & $>0.02$ \\
Functional Impairment score & & & \\
$\quad$ High dose & $30.5 \pm 1.7$ & $22.8 \pm 2.8$ & $<0.05$ \\
$\quad$ Low dose & $31.3 \pm 1.7$ & $30.1 \pm 3.7$ & $>0.2$ \\
Joint tenderness score & & & \\
$\quad$ High dose & $42.0 \pm 7.2$ & $23.1 \pm 3.9$ & $<0.05$ \\
$\quad$ Low dose & $45.9 \pm 5.6$ & $49.3 \pm 11.8$ & $>0.2$ \\
Joint swelling score & & & $<0.01$ \\
$\quad$ High dose & $31.2 \pm 3.5$ & $18.0 \pm 2.7$ & $>0.05$ \\
$\quad$ Low dose & $37.3 \pm 3.9$ & $24.2 \pm 4.1$ & \\
\hline
\end{tabular}

* Values given as mean \pm SE (see ref. 18 for details of scoring).

** Student's two-tailed test.

previous studies have shown that this change in ratio is not due to a selective depletion of $\mathrm{CD}^{+}$cells during radiotherapy, but rather to a failure of $\mathrm{CD} 4{ }^{+}$ cells to repopulate the blood as compared to $\mathrm{CD}^{+}$cells during the several weeks after the completion of TLI (Kotzin et al. 1983). The decreased responses to mitogens and antigens appear to be due to both a reduction in the number of $\mathrm{CD}^{+}$cells and to a functional deficit in the $\mathrm{CD} 4{ }^{+}$cells on a per cell basis (Field et al. 1984). In vitro immunoglobulin synthesis stimulated by pokeweed mitogen was also markedly reduced after high-dose TLI as described before (Kotzin et al. 1981, 1984, Field et al. 1983).

Patients receiving low-dose TLI developed no significant changes in the number or function of the peripheral blood lymphocytes as judged by the various assays mentioned above. Thus, there was a correlation between the immunologic changes and the clinical disease activity changes in the two groups of patients. Whether any of the measured immunologic changes per se cause the reduction in joint inflammation is not clear. Three non-responders in the highdose group showed typical depressions in lymphocyte number and function, and 3 responders in the low-dose group failed to show these changes. However, the chronologic relationship between the prolonged reduction in the number and function of $\mathrm{CD}^{+}$cells and the prolonged reduction in joint disease in most patients suggests that the two changes may be linked (Field et al. 1983). It is of interest that the level of serum autoantibodies such as rheumatoid fac- 


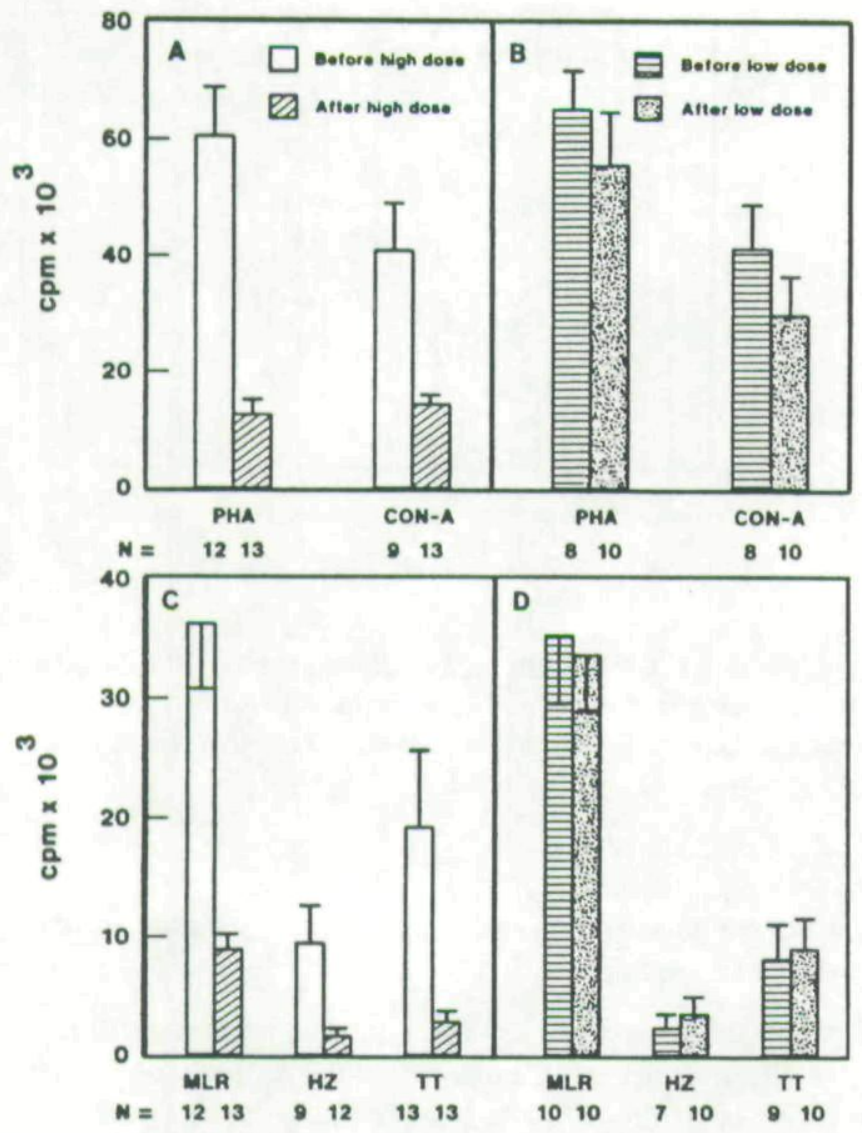

Figure 1. $\left[{ }^{3} \mathrm{H}\right]$-thymidine incorporation and immunoglobulin secretion of peripheral blood mononuclear cell of patients with rheumatoid arthritis given total lymphoid irradiation. Bars show the mean response and brackets show the standard error. a) Proliferative response to phytohemagglutinin (PHA) and concanavalin A (Con A) before and 3 to 6 months after high-dose TLI. b) Proliferative response to PHA and Con A before and after low-dose TLI. c) Proliferative response to allogeneic leukocytes (MLR), herpes zoster antigen (HZ), and tetanus toxoid (TT) before and after high-dose TLI. d) Proliferative response to allogeneic leukocytes, HZ and TT before and after low-dose TLI.

tor (RF) and antinuclear antibodies did not change despite an alleviation in disease activity in high-dose group. This finding has been seen previously (Kotzin et al. 1981, Trentham et al. 1981, Field et al. 1983), and suggests that the serum autoantibodies alone cannot account for the maintenance of joint disease. 


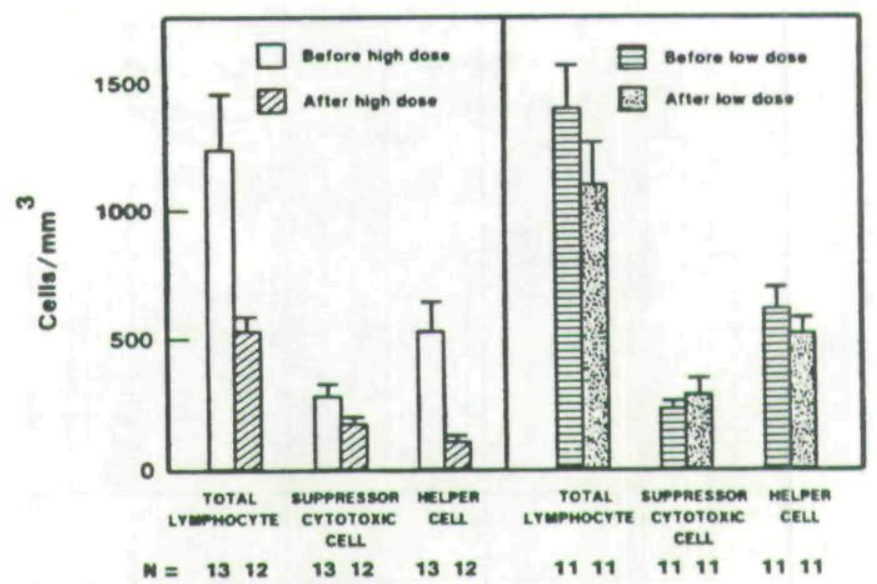

Figure 2. Changes in the absolute numbers of lymphocytes, suppressor/cytotoxic $\mathrm{T}\left(\mathrm{CD} 8^{+}\right)$ cells, and helper/inducer $\mathrm{T}\left(\mathrm{CD}^{+}\right)$cells in the peripheral blood of patients with rheumatoid arthritis given high- or low-dose TLI. The horizontal bars represent the means and the brackets the standard errors. Post-treatment values were obtained 3 to 6 months after TLI. $\mathrm{N}=$ number of patients.

Dissection of the mechanisms of immune injury in the joints in rheumatoid arthritis using total lymphoid irradiation

In another group of 11 patients treated with TLI for intractable RA, a marked diminution in the number of $\mathrm{T}$ cells, particularly those of the helper $\left(\mathrm{CD} 4^{+}\right)$ subset, was observed again, as was a gross impairment of T-cell function (Gaston et al. 1988). Joint disease activity was significantly reduced after TLI as before. In contrast, there was no significant effect of TLI on the levels of RFs of all major immunoglobulin classes within the blood and synovial fluid (Table II). This finding also is clearly consistent with other clinical studies (Kotzin et al. 1981, Trentham et al. 1981, Strober et al. 1985), which showed that levels of IgM, IgG and IgA RFs in both tissues do not change after TLI. Interestingly, work in both humans and experimental animals has shown that TLI suppresses antibody responses to $\mathrm{T}$ cell-dependent antigens, while leaving intact the response to $\mathrm{T}$ cell-independent antigens (Tanay et al. 1984a, 1984b, 1986). This raises the possibility that the production of RF in RA is a T cell-independent process (Tanay et al. 1984a), or it may become T cell-independent during sustained disease. Although RF may contribute to the pathogenesis (Fong et al. 1985), it cannot be the sole contributor, since no change in serum RF occurred at a time of clinical improvement. Furthermore, the increases in levels of IgG-RF and IgA-RF in some patients after TLI is of interest and could suggest a role for T cells in suppressing the production of some RFs. It is worth noting that the dissociation 
TABLE II

Levels of rheumatoid factor $(R F)$ determined by enzyme-linked immuno-adsorbent assay in $R A$ patients before and after $T L I$

\begin{tabular}{lccc}
\hline & Before TLI & After TLI & No. of Patients \\
\hline $\begin{array}{l}\text { Serum: } \\
\text { IgM-RF }\end{array}$ & $0.608 \pm 0.056^{*}$ & $0.671 \pm 0.052$ & 10 \\
IgG-RF & $0.630 \pm 0.097$ & $1.627 \pm 0.191$ & 10 \\
IGA-RF & $1.383 \pm 0.198$ & $1.627 \pm 0.143$ & 10 \\
Synovial Fluid: & & & \\
IgM-RF & $0.650 \pm 0.085$ & $0.502 \pm 0.094$ & 6 pre, 7 post (4 pairs) \\
IgG-RF & $0.181 \pm 0.031$ & $0.219 \pm 0.032$ & 7 (5 pairs) \\
IgA-RF & $0.900 \pm 0.162$ & $1.017 \pm 0.239$ & 7 (5 pairs) \\
\hline
\end{tabular}

* Mean \pm S.E. of ELISA units.

of these two features after treatment with TLI is in contrast to observations made in patients receiving disease-modifying drugs, in whom clinical improvement is associated with a decrease in the serum RF titer (Ward et al. 1983, Jaffe 1965).

Synovial biopsies were obtained from the knees of patients before and after TLI, and spontaneous secretion of IL-2, IFN- $\gamma$, and IL-1 was studied (Gaston et al. 1988). No secretion of IL-2 or IFN- $\gamma$ was detected. However, large amounts of IL-1 were produced by cultured explants before TLI. The most striking change in the synovium following TLI was the marked decrease in the spontaneous secretion of IL-1 by the cultured explants (Table III). Carefully controlled experiments showed that TLI did not produce a general defect in the ability of monocytes/macrophages derived from peripheral blood to secrete IL-1 in response to an appropriate stimulus (Gaston et al. 1988). Immunohistologic staining of

TABLE III

Sponetaneous secretion of IL-1 by synovial biopsy specimens from $R A$ patients obtained before or after TLI

\begin{tabular}{lccc}
\hline Patients & $\begin{array}{c}\text { Before TLI } \\
\text { Units }\end{array}$ & $\begin{array}{c}\text { After TLI } \\
\text { Units }\end{array}$ & $\%$ Change \\
\hline $1^{*}$ & 320 & 80 & -75 \\
$2^{*}$ & 40 & 0 & -100 \\
3 & 10,240 & 160 & -98.5 \\
$4^{*}$ & 160 & 40 & -75 \\
$6^{*}$ & 640 & 0 & -100 \\
$7^{*}$ & 80 & 10 & -88 \\
8 & 10 & 0 & -100 \\
Mean \pm SEM & $1,641 \pm 1,438$ & $41 \pm 22$ & $-91 \pm 4$ \\
Median & 160 & 10 & -94 \\
\hline
\end{tabular}

* Clinical responders. 
synovium with the monoclonal antibody Leu-M3, which identifies monocytes/ macrophages, did not show any diminution in numbers of these cells after TLI. A critical effect of TLI, therefore, appears to be on the spontaneous IL-1 production in the synovium, and not on all potential IL-1-producing cells.

In summary, the clinical improvement that followed TLI in this group of patients was accompanied by a diminution of spontaneous IL-1 secretion by the synovium and marked suppression of T-cell number and function in the peripheral blood, while no quantitative alteration in RFs was observed in either the serum or the joint. IL-1 is not only a growth factor for T and B lymphocytes, it also plays a pivotal role in the pathogenesis of inflammation and cartilage and bone erosion. IL-1 acts on endothelial cells to increase attachment of neutrophils, monocytes and lymphocytes (Bevilacqua et al. 1985, Cavender et al. 1986); this may facilitate recruitment of these cells into the synovium. IL-1 acts on synovial adherent cells to increase secretion of $\mathrm{PGE}_{2}$ and collagenase, on chrondrocytes to induce production of a metalloproteinase that degrades proteoglycan, and on bone to produce demineralization (Mizel et al. 1981, Gowen \& Mundy 1986, Billingham 1985).

Macrophages and other cells in the synovium may be stimulated to produce IL-1 by lymphokines secreted by $\mathrm{T}$ cells that either recognize antigen locally or have been activated elsewhere in the lymphoid system. Peripheral blood lymphocytes and T-cell clones have been shown to produce a factor that stimulates IL1 production by synovial cells (Amento et al. 1982, 1984). A second stimulus to IL-1 secretion may be provided by immune complexes acting on the Fc receptors of macrophages; this mechanism has been demonstrated in vitro using heataggregated IgG and self-associating IgG-RF (Nardella et al. 1983). The fact that levels of IgG-RF in synovial fluid did not change after TLI suggest that this mechanism was not of primary importance in those cases where IL-1 secretion decreased. However, it is possible that subtle changes in the RF or in the function of immune complexes occurred after TLI and were not detected.

Isolation of $\mathrm{CD}^{-} \mathrm{CD}^{-}$and $\mathrm{CD} 4^{+} \mathrm{CD} 8^{-}$mycobacteria-reactive T-lymphocyte clones from rheumatoid arthritis synovial fluid

In view of studies with TLI which suggest a role for T cells in RA, the capacity of mycobacteria-reactive T-cell clones to induce adjuvant arthritis (Holoshitz et al. 1983, 1984), and the vigorous response of RA synovial fluid cells to mycobacterial proteins (Holoshitz et al. 1986), we attempted to establish T-cell clones from RA synovial tissue after repeated stimulations with mycobacterial antigens. Also, the association between the immune response to mycobacterial antigens and HLADR4 (Ottenhoff et al. 1986), a class II MHC antigen commonly associated with RA (Stastny 1978), suggested that this immune response might be related to the pathology of the disease. We established, from a patient with early RA, a T-cell 
line by repeated stimulations of synovial fluid T cells with the acetone-precipitable fraction of mycobacterium tuberculosis (AP-MT) in the presence of irradiated, autologous peripheral blood mononuclear cells (Holoshitz et al. 1989). The resultant line, JBT1, had a mixed phenotype. Flow cytometric analysis showed that $73 \%$ of the cells were $\mathrm{CD} 4^{+} \mathrm{CD} 8^{-}$and $23 \%$ were $\mathrm{CD} 4^{-} \mathrm{CD} 8^{-}$. In unselected synovial fluid, the percentage of double-negative cells was $11 \%$ and in peripheral blood it was $6 \%$. Thus, double-negative T cells were found in a higher percentage in the synovial fluid, and proliferated following repeated stimulations with the mycobacterial antigen AP-MT.

We cloned line JBT1 by the limiting dilution technique and propagated 14 clones successfully. Of the 5 that have been studied in detail, one clone, 1.1 had the $\mathrm{CD}^{+}$ CD8 ${ }^{-} a \beta$ phenotype and 4 clones, $1.2,1.3,1.4$ and 1.6 had the $\mathrm{CD}^{-}{ }^{-} \mathrm{CD} 8^{-} \gamma \delta$ phenotype. Both types of clone proliferated specifically in response to the mycobacterial antigen, AP-MT. The $\gamma \delta$ clone also responded to purified $65 \mathrm{Kd}$ mycobacterial heat-shock protein. Although a relatively crude antigen, AP-MT was not mitogenic in control $\alpha \beta$ and $\gamma \delta$ clones (Holoshitz et al. 1989). The CD4 $4^{-} \mathrm{CD}^{-} \gamma \delta$ clones differed in their MHC restriction pattern from clone 1.1 of the $\mathrm{CD}^{+}{ }^{+} \mathrm{CD}^{-} a \beta$ phenotype. The latter proliferated only in the presence of autologous antigen-presenting cells and its proliferation could be blocked with anti-DR antibodies. In contrast, the $\mathrm{CD}^{-}{ }^{-} \mathrm{CD} 8^{-} \gamma \delta$ clones proliferated in the presence of antigen-presenting cells obtained from different, HLA-disparate, individuals. This proliferation cound not be blocked with anti-class I or anti-class II HLA antibodies (Fig. 3). APMT could be presented to clone 1.3 by Daudi cells which express class II, but not class I antigens. On the other hand, K562, an erythroleukemia line which expresses neither class I nor class II HLA antigens, failed to present the antigen to clone 1.3. Taken together, these results indicate that recognition of AP-MT by the CD4$\mathrm{CD}^{-} \gamma \delta$ clones did not require interaction with class I HLA antigens. Recognition may, however, require presentation by a nonpolymorphic determinant of class II HLA gene produces, or by a different cell surface antigen.

Although both $\mathrm{CD}^{+}{ }^{+} \mathrm{CD} 8^{-} a \beta$ and $\mathrm{CD} 4^{-} \mathrm{CD} 8^{-} \gamma \delta$ clones expressed IL-2 receptors, they differed in their IL-2 production. HT-2 assays of supernatants collected from different clones 24 hours after stimulation with AP-MT in the presence of antigen-presenting cells showed that $\mathrm{CD}^{+}{ }^{+} \mathrm{CD}^{-} \alpha \beta$ but not $\mathrm{CD}^{-}$ $\mathrm{CD}^{-} \gamma \delta$ clones produced HT-2-stimulating lymphokines (IL-2 or IL-4). CD4$\mathrm{CD}^{-} \gamma \delta$ clones failed to produce such lymphokines even when stimulated with mitogens, such as PHA or anti-CD3 antibodies. Both types of clone produced IFN- $\gamma$ when stimulated with AP-MT.

Preliminary experiments to characterize the structure and function of the TCR's of the $\mathrm{CD}^{-} \mathrm{CD}^{-} \gamma \delta$ clones have been carried out. In a monoclonal antibody inhibition test, it was found that proliferation in response to AP-MT of clone 1.3 could be blocked with a monoclonal antibody against CD3 and with the monoclonal antibody Ti- $\gamma \mathrm{A}$ specific for $\mathrm{V} \gamma 9$ gene product, which has been found to be 


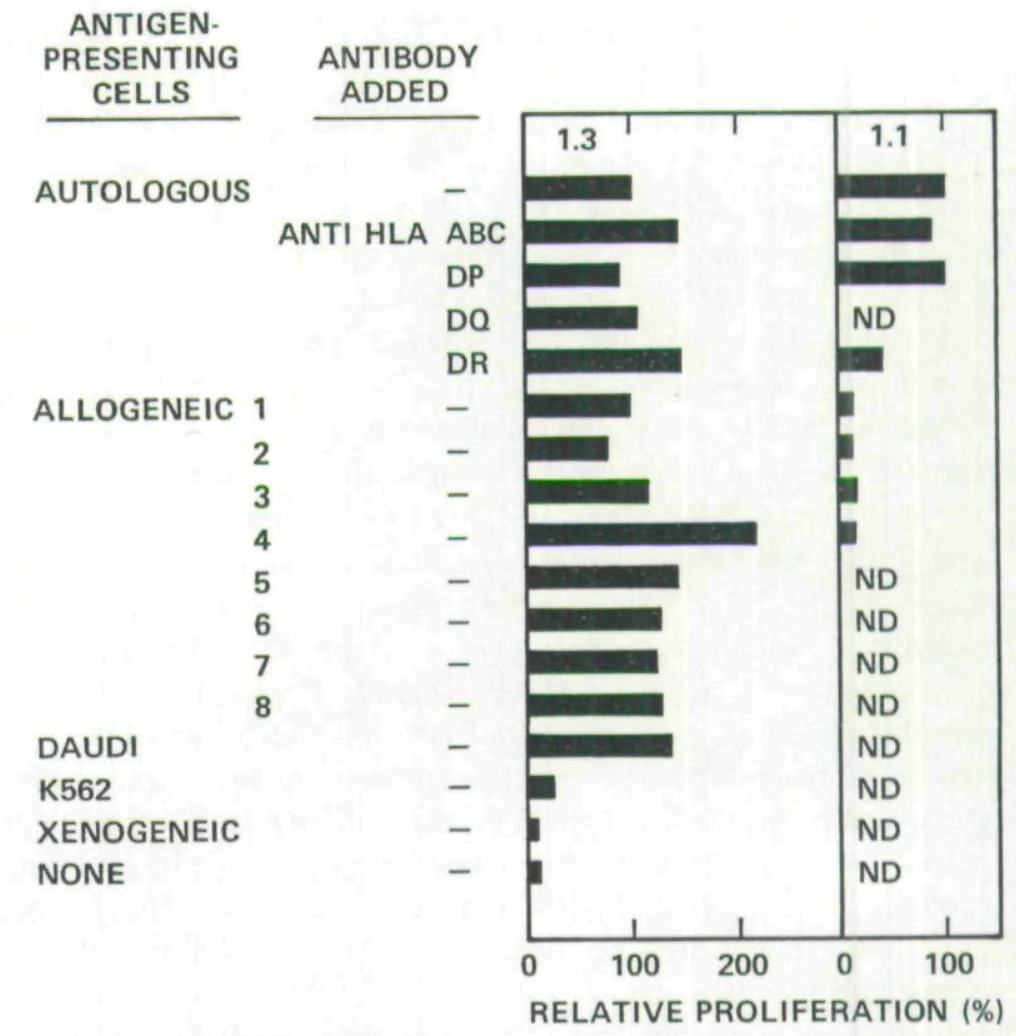

Figure 3. Proliferation of $\gamma \delta$ clones to AP-MT is MHC non-restricted. $\gamma \delta$ clones represented here by clone 1.3 (left side) proliferated in the presence of both autologous and allogeneic antigen-presenting cells obtained from randomly selected nonrelated individuals. HLA typing was disparate among the allogeneic and autologous cells (not shown). Proliferation of $\gamma \delta$ clones could not be blocked by anti-class I or class II HLA antibodies. Results are expressed as relative proliferation (stimulation index obtained in the specificed test conditions divided by the stimulation index obtained in the presence of autologous antigen present cells $(\times 100))$.

expressed by all the $\mathrm{CD}^{-}{ }^{-} \mathrm{CD} 8^{-} \gamma \delta$ clones (see below). The inhibitory effect of Ti- $\gamma$ A monoclonal antibody was specific, as this antibody failed to inhibit antigenspecific proliferation of a control, $\mathrm{CD}^{+}{ }^{+} \mathrm{CD}^{-} \alpha \beta$ anti-tetanus toxoid T-cell line. Other monoclonal antibodies against the $\mathrm{V} \delta 1$ gene product (which is not expressed by these cells, see below), against the CD4 receptor, and against CD20 receptor, all failed to inhibit proliferation of clone 1.3.

FACS and immunoprecipitation analyses (Holoshitz et al. 1989) have indicated that the TCR's of the $4 \mathrm{CD}^{-}{ }^{-} \mathrm{CD} 8^{-} \delta \gamma$ clones were composed of disulfidelinked heterodimers of a $\delta$ chain bearing the $\mathrm{V} \gamma 9$ gene product (as indicated by 
positive staining with the monoclonal antibody Ti- $\gamma \mathrm{A}$ ) and a $\delta$ chain bearing a $\mathrm{V}$ region different from the one encoded by $\mathrm{V} \delta 1$ (as indicated by negative staining with the monoclonal antibody $\delta \mathrm{TCS} 1$, which recognizes the $\mathrm{V} \delta 1$ gene product). Southern blot analysis of Bg1 II-digested DNA, probed with a $\mathrm{J} \delta 1$ probe, revealed a rearranged band of $7.8 \mathrm{~Kb}$ in 3 out of $3 \mathrm{CD}^{-} \mathrm{CD} 8^{-} \gamma \delta$ clones that have been tested. These bands were clearly distinct from the $5.2 \mathrm{~Kb}$ rearranged band corresponding to $\mathrm{V} \delta 1$, found in Peer and Molt 13 cells and from the Bgl II 4.2 $\mathrm{Kb}$ band found in cells which rearrange the $\mathrm{V} \delta 2$ gene segment and from the 9.6 $\mathrm{Kb}$ band found in cells which rearrange $\mathrm{V} \delta 3$ segments. Clone 1.2 showed an additional, $9.4 \mathrm{~Kb}$ rearranged band which may represent a second allele (E. Loh, J. Holoshitz \& S. Strober, in preparation).

Takihara et al. (1989) have recently identified three additional $\mathrm{V} \delta$ gene segments, $\mathrm{V} \delta 4, \mathrm{~V} \delta 5$ and $\mathrm{V} \delta 6$. To test whether any of these $\mathrm{V} \delta$ segments is used by our clones, we have used the polymerase chain reaction (PCR). cDNA was reverse transcribed from total RNA. Amplification attempts using oligonucleotides specific to each of these $\mathrm{V} \delta$ segments as $5^{\prime}$ primers along with a $\mathrm{J} \delta 1$ oligonucleotide as a $3^{\prime}$ primer revealed transcripts in peripheral blood $\gamma \delta \mathrm{T}$ cells from a normal individual, but did not reveal any transcipt in our clones. These results, along with the Southern blot analysis suggest that the $\mathrm{CD} 4^{-} \mathrm{CD} 8^{-} \gamma \delta$ clones that we have tested use a unique, or otherwise rare, $\mathrm{V} \delta$ gene segment.

Oligonucleotide sequencing of cDNA of the $\gamma$ chain from $3 \gamma \delta$ T-cell clones revealed identical usage of $\mathrm{V} \gamma 9$ and $\mathrm{J}$ segment with $\mathrm{N}$-region diversity (E. Loh, J. Holoshitz \& S. Strober, in preparation).

\section{T lymphocyte-synovial fibroblast interactions induced by mycobacterial proteins in rheumatoid arthritis}

To gain a better understanding of the nature of the interaction between mycobacteria-reactive $\mathrm{T}$ cells and synovial cells, and to study the role that $\mathrm{T}$ cells and other synovial cells play in the formation of the inflamed synovial joint tissues (pannus), an in vitro system was developed.

Synovial biopsy specimens were obtained from the joints of 15 patients with RA, 11 with degenerative joint disease (DJD), and one each with ankylosing spondylitis, Lyme arthritis and gout. In most cases, the patient's diagnosis was unknown at the time the biopsy specimen was acquired, and the diagnosis was determined by a review of the in-patient records after the in vitro studies were completed.

Synovial membranes from patients were mechanically dissociated, and cells were washed in phosphate buffered saline (PBS) and passed through a nytex mesh to remove cell aggregates. Mononuclear cells were obtained from a FicollHypaque density gradient $(400 \times g$ for $30 \mathrm{~min})$. Following three washings in PBS, the cells were incubated in 24-well plates, $10^{6}$ cells per well in RPMI 1640 medium 
containing $10 \mu \mathrm{g} / \mathrm{ml}$ of the mycobacterial extract (AP-MT), $10 \%$ fetal calf serum, $2 \mathrm{mM}$ L-glutamine, $10 \mathrm{mM}$ Hepes and antibiotics. After 6 days of incubation, 1 $\mathrm{ml}$ of cell-free supernatant was removed from each well and $1 \mathrm{ml}$ of fresh medium containing $10-20 \mathrm{U} / \mathrm{ml}$ of recombinant human IL-2 was added. Cultures were subsequently fed with IL-2-containing medium every $3 \mathrm{~d}$ and followed microscopically to detect cell-growth characteristics.

Dissociated synovial cells from RA patients were cultured in the presence or absence of the mycobacterial extract AP-MT, and observed with an inverted microscope. In cultures containing AP-MT, foci of fibroblastoid cells and small lymphocytes started multiplying in close proximity to each other mainly at the periphery of the well, as early as 1 week after plating. The fibroblasts in these areas created condensed areas which gradually formed ridge-like masses by 2 to $3 \mathrm{wk}$. Some condensed areas then detached from the bottom and formed macroscopic tissue outgrowths suspended in the medium by 4 to $6 \mathrm{wk}$ (Fig. 4a).

Small mononuclear cells interspersed with fibroblastoid cells were present on the bottom of the wells with tissue outgrowths. The lymphocytes collected at the bottom were shown to be T cells using FACS analysis of ficoll-purified mononu-

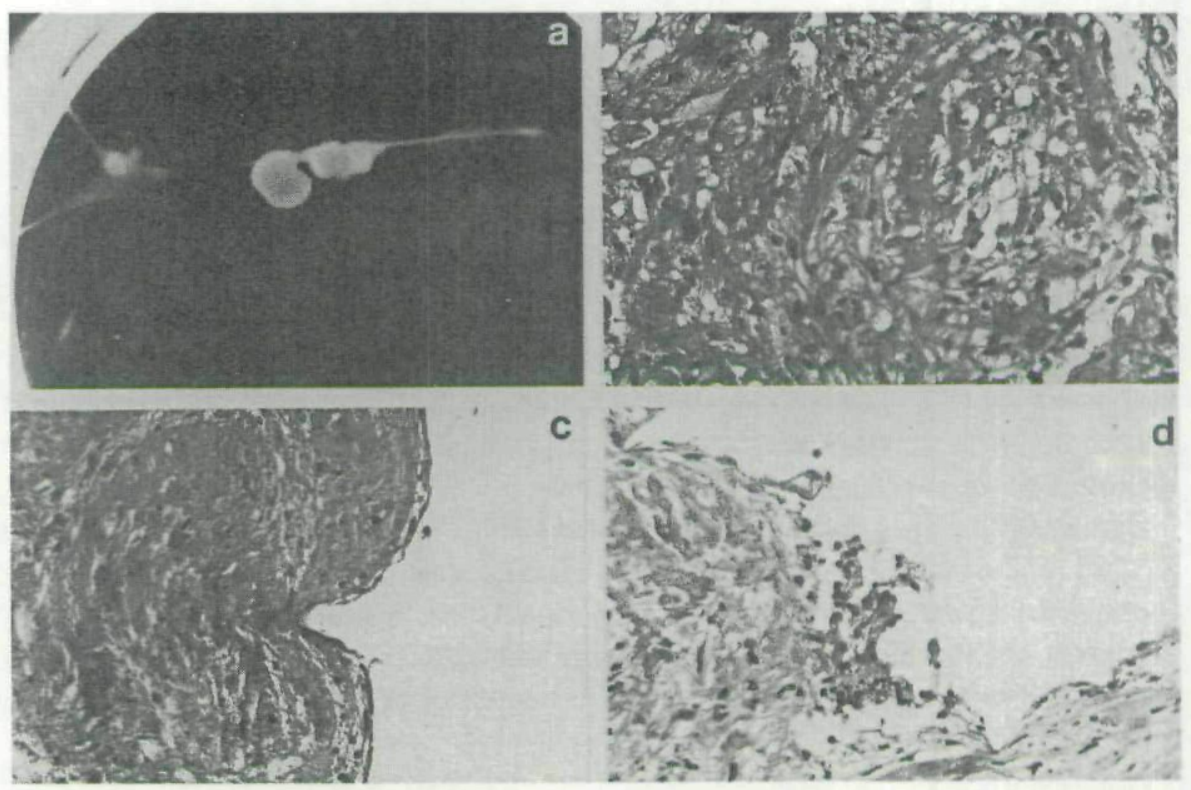

Figure 4. Characteristics of synovial cell outgrowths from patients with RA. (a) Macroscopic tissue outgrowth, $\times 80$ original size; (b-d) Histopathologic micrographs of an in vitro tissue outgrowth stained with hematoxylin and eosin, (b) concentric swirls of mononuclear cells in an extracellular matrix $(\times 200)$, (c) fibrin matrix with mononuclear cells, (d) lymphocytes attached to the outer surface of the stained tissue mass $(\times 200)$. 
clear cells; the markers depended on the particular culture chosen. Some cultures showed predominance of T cells with CD4 markers; others showed mixtures of CD3-positive cells which had variable expression of CD4 and CD8 markers with a high proportion of double-negative cells (Table IV). These residual single cell suspensions could be transferred serially at least six times to new wells to observe tissue outgrowth of this type. In cultures without AP-MT, fibroblast-like cells became gradually predominant and formed homogenous monolayers which occupied, after 2-4 wk, the entire area of the tissue culture well without tissue outgrowths.

The macroscopic tissue outgrowths were studied histologically. Hematoxylin and eosin staining showed well-organized tissues, and certain areas were composed of small cells arranged in concentric swirls with prominent nuclei (Fig. 4b). Other portions contained a cellular eosinophilic material in which some large cells were visible (Fig. 4c). Lymphocytes could be seen mainly at the periphery, attached to the outer surface of the tissue masses (Fig. 4d). The entire tissue mass was surrounded by a thin layer of flat cells (Fig. 4c).

The ability to obtain macroscopically visible outgrowths was tested in 15 patients with RA. As shown in Table V, 14 of 15 patients tested produced outgrowths. On the other hand, only 3 of 14 patients without RA (2 with degenerative joint disease (DJD) and one with ankylosing spondylitis) showed outgrowths. Thus, the phenomenon was found in almost all patients with RA, and in a minority with DJD. However, too few patients with other forms of inflammatory arthritis were tested to assess the frequency of outgrowths in a specific inflammatory arthritic disease, such as ankylosing spondylitis.

To better characterize the cells which form the tissue masses, frozen sections of the tissue outgrowths identified in Table $\mathrm{V}$ were stained with a variety of monoclonal antibodies, using the immunoperoxidase technique. The fibroblasts expressed class I and class II antigens, as well as the intercellular adhesion molecules, ICAM-1 and LFA-3 (Table VI). T lymphocytes found mainly in the periphery of the outgrowth masses were both of the CD4 and the CD8 phenotype and expressed CD2 antigens on their surface. Some cells expressed LFA-1 surface

TABLE IV

FACS analysis of cultured synovial cells after immunofluorescent staining (percentage)

\begin{tabular}{lrrc}
\hline Culture & $\mathrm{CD}^{+}$ & $\mathrm{CD}^{-}$ & $\mathrm{CD}^{-} \mathrm{CD}^{-}$ \\
\hline 1 & 7.3 & 61.7 & 19.6 \\
2 & 16.7 & 25.8 & 19.9 \\
3 & 52.1 & 34.4 & 8.4 \\
4 & 63.7 & 21.2 & 5.5 \\
5 & 7.2 & 29.3 & 49.2 \\
6 & 6.6 & 43.4 & 25.1 \\
\hline
\end{tabular}


TABLE V

Tissue outgrowth in patients with different forms of arthritis

\begin{tabular}{|c|c|c|c|c|c|}
\hline \multicolumn{3}{|c|}{ Rheumatoid Arthritis (RA) } & \multicolumn{3}{|c|}{ Non-RA } \\
\hline Diagnosis & Patient \# & $\begin{array}{c}\text { Tissue } \\
\text { Outgrowth }\end{array}$ & Diagnosis & Patient \# & $\begin{array}{c}\text { Tissue } \\
\text { Outgrowth }\end{array}$ \\
\hline \multirow[t]{16}{*}{$\mathrm{RA}$} & ${ }^{*} 1$ & + & Degenerative Joint & ${ }^{*} 1$ & - \\
\hline & *2 & + & $\begin{array}{l}\text { Disease } \\
\text { (DJD) }\end{array}$ & *2 & - \\
\hline & 3 & + & & *3 & + \\
\hline & *4 & + & & $* 4$ & - \\
\hline & 5 & + & & $* 5$ & - \\
\hline & *6 & + & & *6 & - \\
\hline & *7 & + & & *7 & - \\
\hline & $* 8$ & + & & *8 & - \\
\hline & *9 & + & & *9 & + \\
\hline & 10 & + & & 10 & - \\
\hline & *11 & - & & 11 & - \\
\hline & *12 & + & Ankylosing spondylitis & *12 & + \\
\hline & *13 & + & Lyme Arthritis & 13 & - \\
\hline & 14 & + & Gout & 14 & - \\
\hline & 15 & + & & & \\
\hline & Total & $14 / 15$ & & & $3 / 14$ \\
\hline
\end{tabular}

* blind follow-up - patient diagnosis not obtained until culture recorded as positive or negative.

TABLE VI

In vitro pannus: Immunohistology

\begin{tabular}{lc}
\hline Antigen & $\begin{array}{c}\text { Immunoperoxide } \\
\text { Staining }\end{array}$ \\
\hline HLA A, B, C & + \\
DR & ++ \\
DP & + \\
DQ & ++ \\
LFA 1 & + \\
2 & ++ \\
3 & + \\
ICAM & + \\
CD 1 & + \\
CD 4 & + \\
CD 8 & ++ \\
Macrophages & - \\
Collagen Type I & - \\
\hline
\end{tabular}


antigens. Immunoperoxidase staining of a relatively early tissue (3 wk) revealed the presence of macrophages stained with the monoclonal antibody EMB11.

The details of cellular interactions during early tissue outgrowth were studied using the electron microscope. Scanning electron micrographs showed that, in positive cultures, lymphocytes were attached to the fibroblast layers (Fig. 5) and in negative cultures only bare monolayers of fibroblasts were observed. Higher magnification of individual lymphocytes showed formation of pseudopods or "foot processes" by the adherent lymphocytes. These processes formed a close contact area between the membrane of the lymphocyte and that of the fibroblast. Further magnification of the contact area (Fig. 6) revealed fibrillar and microtubular structures perpendicular to the plane of the interface. Immunogold staining using anti-CD3 monoclonal antibody (OKT3) showed that most lymphocytes expressed the $\mathrm{CD} 3$ antigen and, thus, were $\mathrm{T}$ cells.

To determine whether the tissue outgrowth was dependent on the antigenic
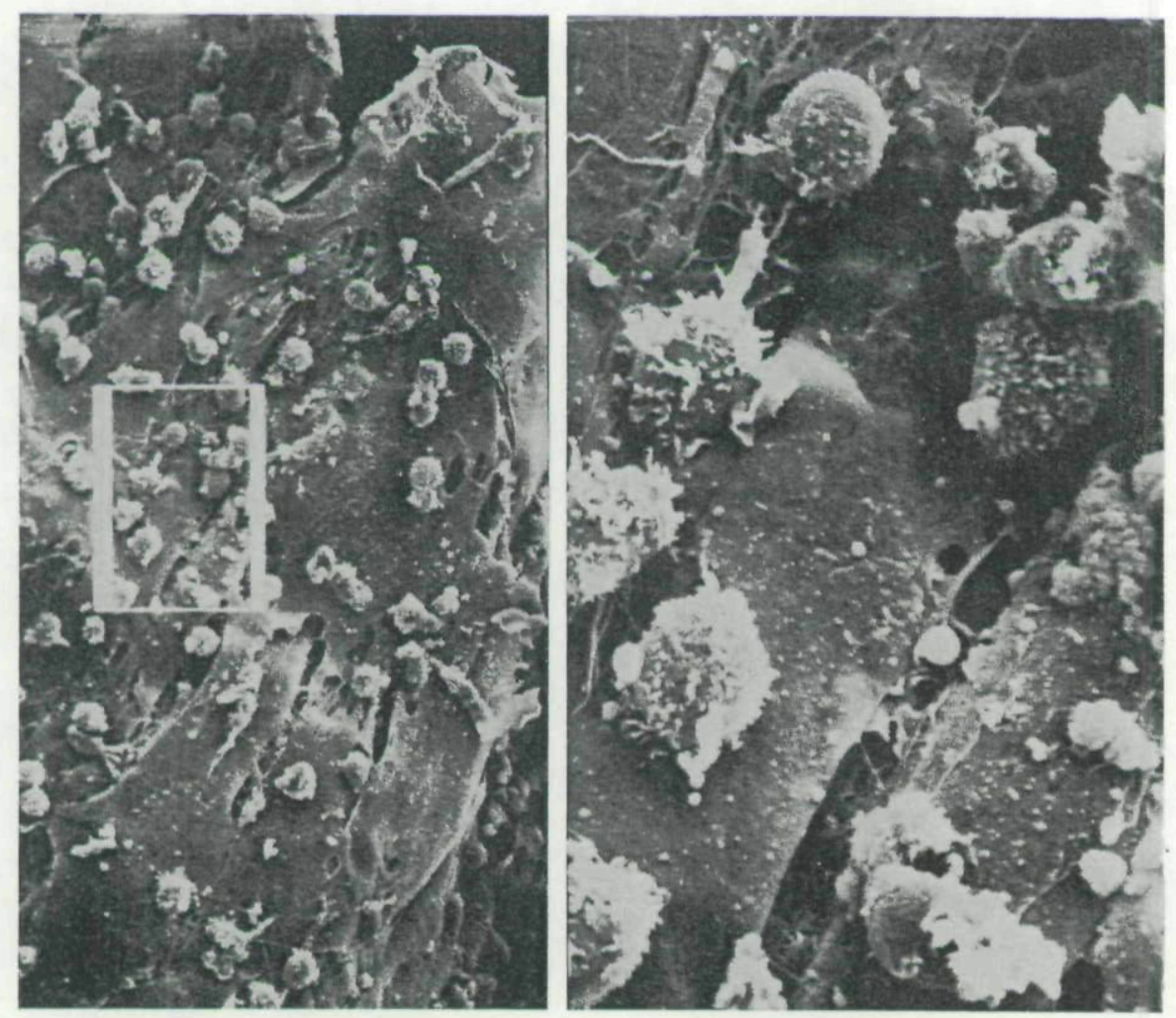

Figure 5. Scanning electron micrographs of synovial cell cultures. Positive culture from a patient with RA showing lymphocytes adhering to fibroblasts (left panel $\times 400$, right panel $\times 2000$ ). 
specificities of the mycobacterial protein in the initial 6-d culture period, another bacterial protein, tetanus toxoid, was tested as a substitute. In the first series of experiments, the synovial cells were incubated with either $10 \mu \mathrm{g} / \mathrm{ml}$, AP-MT, or a dilution (1:1000) of tetanus toxoid (TT) (Commonwealth of Massachusetts, Department of Public Health, Jamaica Plains, MA) previously shown to activate $\mathrm{T}$ cells (Field et al. 1984), or no antigen for the first $6 \mathrm{~d}$, and then with $10 \mathrm{U} / \mathrm{ml}$ IL-2 being added to the cultures (Table VII). Twenty-two of the 32 wells cultured with AP-MT showed positive outgrowths, while none of the eight wells incubated with TT, and only one of the 22 wells incubated with no antigen showed an outgrowth.

In the second series of experiments, the role of IL-2 in the formation of tissue outgrowth was studied. Established cultures were split and propagated under various tissue culture conditions. Thirteen of 16 transfers showed positive outgrowth of tissue masses when IL-2 was supplemented (Table VII). None of the

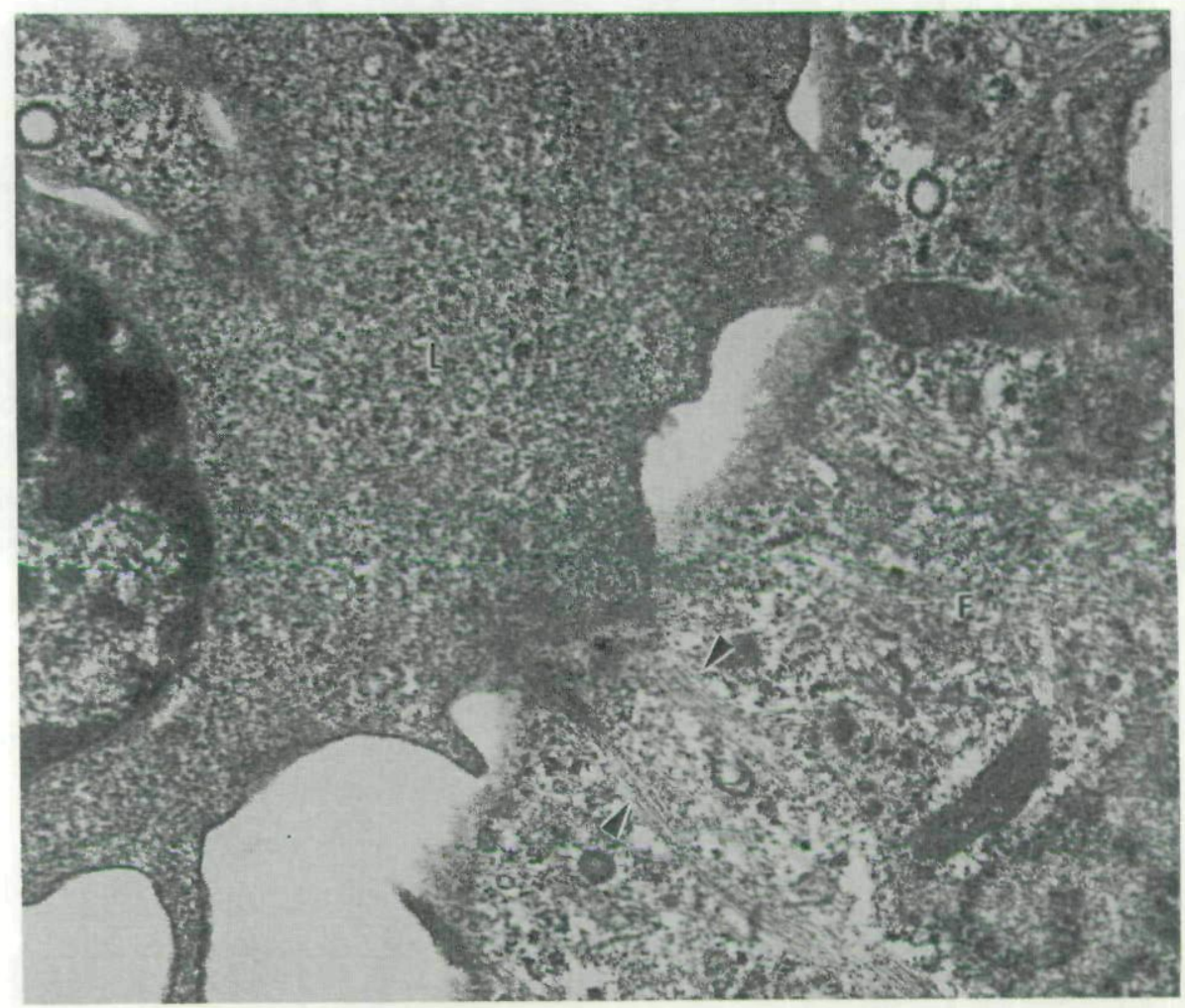

Figure 6. Transmission electron micrograph (TEM) of contact area between lymphocyte and fibroblast; Lymphocyte-fibroblast interface with fibril orientation (arrows) perpendicular to the interface of both cells similar to desmosomal structure (TEM, $\times 16000)$. 
six cultures propagated in IL-2-free medium showed this phenomenon. When cyclosporin A (1 $\mu \mathrm{g} / \mathrm{ml})$ was added to IL-2-containing cultures, none of the six transfers showed positive outgrowth (Table VII). To directly study the role of T cells in tissue outgrowth, soluble anti-CD3 antibodies (OKT3, $125 \mathrm{ng} / \mathrm{ml})$ were added at the time of plating of the synovial cells in the presence of AP-MT. In four cultures, cell growth was almost completely inhibited, such that at 2 wk only a rare fibroblast was observed (Table VII).

These experiments show that dissociated synovial biopsy cells from most RA patients can be stimulated in vitro with a single exposure to crude mycobacterial extract and culture medium enriched with IL-2 to form an organized tissue which has the microscopic appearance of the inflamed synovium (pannus) in RA. This indicates that the fibroblasts proliferate and secrete an extracellular collagenous matrix during the culture period.

During the first $2 \mathrm{wk}$ of culture, attachment of lymphocytes to fibroblasts was clearly documented by scanning and transmission electron microscopy. Lymphocyte foot processes were observed attached to the fibroblast cell surface with underlying perpendicular fibrillar arrays. Microtubular rearrangements have previously been described during antigen-specific stimulation of $\mathrm{T}$ cells by antigenpresenting cells (Kupfer et al. 1987). In addition, Haynes and his colleagues have reported that $\mathrm{T}$ cells conjugate with synovial fibroblasts in in vitro via interactions which involve the CD2 and LFA-3 surface receptors (Haynes et al. 1988). However, these interactions have not been observed previously in the context of dissociated cell suspensions going on to form an organized tissue with an extracellular matrix. It is of interest that the tissue outgrowths stained positively for both CD2 and LFA-3 markers which appear to play a role in T cell-fibroblast conjugation (Haynes et al. 1988).

It is not clear whether the in vitro outgrowth of tissue mimics the processes in

TABLE VII

Effect of changes in culture medium on tissue outgrowth

\begin{tabular}{llcccc}
\hline Exp. & Antigen & $\begin{array}{c}\text { Cyclo- } \\
(10-20 \mathrm{U} / \mathrm{ml})\end{array}$ & $\begin{array}{c}\text { Anti-CD3 } \\
\text { Antibody } \\
(1 \mu \mathrm{g} / \mathrm{ml})\end{array}$ & $\begin{array}{c}\text { Ratio of Positive } \\
(\mathrm{OKT} 3) \\
(125 \mathrm{ng} / \mathrm{ml})\end{array}$ & $\begin{array}{c}\text { Wells to } \\
\text { No. of Wells Plated }\end{array}$ \\
\hline 1. & AP-MT & + & - & - & $22 / 32$ \\
& Tetanus Toxoid & + & - & - & $0 / 8$ \\
& None & + & - & - & $1 / 22$ \\
2. & AP-MT & + & - & - & $13 / 16$ \\
& AP-MT & - & - & - & $0 / 6$ \\
& AP-MT & + & + & - & $0 / 6$ \\
& AP-MT & + & - & + & $0 / 4$ \\
\hline
\end{tabular}

+ or - indicates presence or absence of reagents. 
the outgrowth of inflamed synovium in vivo in the joints of patients with RA or other inflammatory arthritides. However, the assay described herein may provide a tool for the study of a mutually stimulatory interaction of $\mathrm{T}$ cells and fibroblasts which may play a role in the immune injury of joint tissues.

\section{SUMMARY AND CONCLUSION}

Evidence for the involvement of $\mathrm{T}$ cells, especially $\mathrm{CD} 4^{+} \mathrm{T}$ cells, in the pathogenesis of RA is substantial and includes 1) the correlation between prolonged $\mathrm{CD}^{+}{ }^{+} \mathrm{T}$-cell depletion and improvement in joint disease in the absence of observable changes in the levels of autoantibodies (rheumatoid factors) in the blood and joints, 2) the infiltration of the inflamed synovial tissues with T cells and, 3) the increased susceptibility of individuals to RA with certain HLA-DR haplotypes. The most direct evidence for the involvement of $\mathrm{CD}^{+} \mathrm{T}$ cells is provided by recent studies which demonstrate rapid improvement in the joint disease manifestations of RA following the infusion of anti-CD4 monoclonal antibodies (Herzog et al. 1989, Walker et al. 1989).

It is unlikely that $\mathrm{T}$ cells alone are responsible for the joint injury in RA. Autoantibodies (rheumatoid factors) in the joint which contribute to the release of complement breakdown products, and to the secretion of cytokines such as IL-1 by macrophages must also play an important role. Indeed, depletion of $\mathrm{CD} 4{ }^{+}$cells after TLI or therapy with monoclonal antibody reduces, but does not eliminate, joint disease activity. The residual joint disease activity is probably influenced by the continued contribution of autoantibodies to joint injury. Production of these autoantibodies may not be dependent on help from $\mathrm{CD} 4^{+}$cells, since little change is observed in autoantibody levels after $\mathrm{CD} 4^{+}$cell depletion.

The mechanisms by which $\mathrm{T}$ cells mediate to the joint disease in RA are not clear. Little or no direct evidence of cytotoxic effects of $\mathrm{T}$ cells on autologous joint cells has been reported. Considerable evidence suggests that at least some T-cell cytokines (i.e., TNF $a$, IL-6) can contribute to the proliferation of synovial lining cells which results in the marked build-up of inflammatory tissue (pannus) in the joints of patients with RA (Firestein et al. 1990). In addition, T cells may recruit other joint cells, such as macrophages, to secrete cytokines (i.e., IL-1) which both contribute to synovial cell proliferation, and cartilage and bone degeneration. The marked reduction in the sponetaneous secretion of IL-1 by synovial biopsies, and improvement in disease activity after TLI support this notion. Interestingly, the $\mathrm{CD} 4^{+} \mathrm{T}$-cell lymphokines, IL-2 and IFN- $\gamma$, were not spontaneously secreted in detectable quantities by synovial biopsies. This suggests that the pattern of lymphokines secreted by $\mathrm{T}$ cells in the joint in RA are not typical of that in delayed-type hypersensitivity reactions.

The studies of the in vitro culture of mixtures of $\mathrm{T}$ cells and synoviocytes from RA joints also provide evidence for the direct role of $\mathrm{T}$ cells in the proliferation 
of synoviocytes and their subsequent organization into an inflammatory tissue, since anti-CD3 monoclonal antibodies completely inhibited the outgrowth of these tissues. The requirement for exogenous IL-2 for outgrowth is consistent with the lack of spontaneous secretion of the lymphokine by synovial biopsies, and suggests that the fresh or cultured joint T cells secrete little IL-2.

Assuming that $\mathrm{T}$ cells play an important role in the effector mechanisms of RA, what immunogenic epitopes in the joint are recognized by the $T$ cells? Evidence is presented for the role of mycobacterial proteins, especially $65 \mathrm{Kd}$ heat-shock proteins in the recognition phase. This could be due to the recognition of peptides derived from human heat-shock proteins which are expressed on the surface of joint cells. Thus, target cells in the joint may aberrantly express the heat-shock protein-derived peptides, which bind to the T-cell antigen receptor, and activate $\mathrm{T}$ cells in the joints. Alternatively, peptides derived from other joint constituents such as proteoglycans may crossreact with the heat-shock protein epitopes, and activate $\mathrm{T}$ cells by virtue of this crossreactivity. The recognition of mycobacterial heat-shock proteins by joint fluid $\mathrm{T}$ cells may be an accidental byproduct of such an autoimmune process. Alternatively, the immune response to bacterial heat-shock proteins may have initiated the autoimmune process.

The presence of a high proportion of $\gamma \delta^{+} \mathrm{T}$-cell clones after multiple in vitro stimulations of RA synovial T cells with mycobacterial proteins is consistent with reports that the repertoire of $\gamma \delta^{+}$T-cell receptors is skewed toward recognition of mycobacterial and mammalian heat-shock protein epitopes (Asarnow et al. 1988, Haregewoin et al. 1989, O'Brien et al. 1989, Born et al. 1990). Our preliminary results which indicate that the synovial cell outgrowth in vitro can be inhibited by monoclonal antibodies to the $\gamma \delta$ TcR suggest that $\gamma \delta^{+} \mathrm{T}$ cells may play a role in synovial cell proliferation, and that both $\gamma \delta^{+}$and $\mathrm{CD}^{+} \mathrm{T}$ cells may play necessary, but partial roles in the chain of events that results in immune injury in RA.

\section{REFERENCES}

Amento, E. P., Kurnick, J. T., Epstein, A. \& Krane, S. M. (1982) Modulation of synovial cell products by a factor from a human cell line: T lymphocyte induction of a mononuclear cell factor. Proc. Natl. Acad. Sci. USA 79, 5307.

Amento, E. P., Kurnick, J. T. \& Krane, S. M. (1984) Interleukin 1 production by the human monocyte line U937 requires a lymphokine induction signal distinct from interleukin 2 or interferons. J. Immunol. 134, 350.

Asarnow, D. M., Kuziel, W. A., Bonyhadi, M., Tigelaar, R. E., Tucker, P. W. \& Allison, F. P. (1988) Limited diversity of gamma delta antigen receptor genes of Thy-1 + dendritic epidermal cells. Cell 55 (5), 837.

Bevilacqua, M. P., Pober, J. S., Wheeler, M. E., Cotran, R. S. \& Gimbrone, M. A. Jr. (1985) Interleukin 1 acts on cultured human vascular endothelium to increase the adhesion of polymorphonuclear leukocytes, monocytes, and related leukocyte cell lines. J. Clin. Invest. 76, 2003. 
Billingham, M. E. J. (1983) Interleukin-1: its relevance to rheumatoid arthritis. Br. J. Rheumatol. 24 (suppl), 25.

Born, W., Hall, L., Dallas, A., Boymel, J., Shinnick, T., Young, D., Brennan, P. \& O'Brien, B. (1990) Recognition of a peptide antigen by heat shock reactive $\gamma \delta$ T lymphocytes. Science 249, 67.

Cavender, D. E., Haskard, D. O., Joseph, B. \& Ziff, M. (1986) Interleukin 1 increases the binding of human B and T lymphocytes to endothelial cell monolayers. J. Immunol. 136, 203.

Duke, O., Panayi, G. S., Janossy, G. \& Poulter, L. W. (1982) Immunohistological analysis of lymphocyte subpopulations and their micro-environment in the synovial membranes of patients with rheumatoid arthritis using monoclonal antibodies. Clin. Exp. Immunol. 49, 22.

Field, E. H., Engleman, E. G., Terrell, C. P. \& Strober, S. (1984) Reduced in vitro immune responses of purified human Leu-3 (helper/induce phenotype) cells after total lymphoid irradiation. J. Immunol. 132, 1031.

Field, E. H., Strober, S., Hoppe, R. T., Calin, A., Engleman, E. G., Kotzin, B. L., Tanay, A. S., Calin, H. J., Terrell, C. P. \& Kaplan, H. S. (1983) Sustained improvement of intractable rheumatoid arthritis after total lymphoid irradiation. Arthritis Rheum. 26, 937.

Firestein, G. S. \& Zvaifler, N. J. (1990) How important are T cells in chronic rheumatoid synovitis? Arthritis Rheum. 33, 768.

Fong, S., Carson, D. A. \& Vaughan, J. H. (1985) Rheumatoid factor. In: Immunology of Rheumatic Diseases, eds Gupta, S., \& Talal, N. Plenum Publishing, New York. p. 167.

Fuks, Z., Strober, S., Bobrove, A. M., Sasazuki, T., McMichael, A. \& Kaplan, H. S. (1976) Long term effects of irradiation on $\mathrm{T}$ and $\mathrm{B}$ lymphocytes in peripheral blood of patients with Hodgkin's disease. J. Clin. Invest. 58, 803.

Gaston, J. S. H., Strober, S., Solovera, J. J., Gandour, D., Lane, N., Schurman, D., Hoppe, R. T., Chin, R. C., Eugui, E. M., Vaughan, J. H. \& Allison, A. C. (1988) Dissection of the mechanisms of immune injury in rheumatoid arthritis using total lymphoid irradiation. Arthritis Rheum. 31, 21.

Gowen, M. \& Mundy, R. (1986) Actions of recombinant interleukin 1, interleukin 2, and interferon- $\gamma$ on bone resorption in vitro. J. Immunol. 136, 2478.

Haregewoin, A., Soman, G., Horn, R. C. \& Finberg, R. W. (1989) Human $\gamma \delta+$ T cells respond to mycobacterial heat shock protein. Nature 340, 309.

Harris, E. D., Jr. (1990) Rheumatoid Arthritis: pathophysiology and implications of therapy. New Engl. J. Med. 322, 1277.

Haynes, B. F., Grover, B. J., Whichard, L. P., Hale, L. P., Nunley, J. A., McCollum, D. E. \& Singer, K. H. (1988) Synovial micro-environment T cell interactions. Human T cells bind to fibroblast-like synovial cells in vitro. Arthritis Rheum. 31, 947.

Herzog, C., Walker, C., Muller, W., Riethmuller, G., Muller, W. \& Pichler, W. J. (1989) Anti-CD4 antibody treatment of patients with rheumatoid arthritis. I. Effect on clinical course and circulating T cells. J. Autoimmun. 2, 627.

Holoshitz, J., Klajman, A., Drucker, I., Lapidot, S., Yaretzky, A., Frenkel, A., van Eden, W. \& Cohen, I. R. (1986) T lymphocytes of rheumatoid arthritis patients show augmented reactivity to a fraction of mycobacteria cross-reactive with cartilage. Lancet $\mathbf{I}, 305$.

Holoshitz, J., Naparstek, Y., Ben-Nun, A. \& Cohen, I. R. (1983) Lines of T lymphocyte induce or vaccinate against autoimmune arthritis. Science 219, 56.

Holoshitz, J., Matitiau, A. \& Cohen, I. R. (1984) Arthritis induced in rats by cloned T lymphocytes responsive to mycobacterial but not to collagen type II. J. Clin. Invest. 73, 211.

Jaffe, I. A. (1965) The effect of penicillamine on the laboratory parameters in rheumatoid arthritis. Arthritis Rheum. 8, 1064. 
Klareskog, L., Forsum, U., Wigren, A. \& Wigzell, H. (1982) Relationships between HLADR-expressing cells and $\mathrm{T}$ cells of different subsets in rheumatoid arthritis synovial tissue. Scand. J. Immunol. 15, 501.

Kotzin, B. L., Kansas, G. S., Engleman, E. G., Hoppe, R. T., Kaplan, H. S. \& Strober, S. (1983) Changes in T cell subsets in patients with rheumatoid arthritis treated with total lymphoid irradiation. Clin. Immunol. Immunopathol. 27, 250.

Kotzin, B. L. \& Strober, S. (1979) Reversal of NZB/NZW disease with total lymphoid irradiation. J. Exp. Med. 150, 371.

Kotzin, B. L., Strober, S., Engleman, E. G., Calin, A., Hoppe, R. T., Kansas. G. S., Terrell, C. P. \& Kaplan, H. S. (1981) Treatment of intractable rheumatoid arthritis with total lymphoid irradiation. N. Engl. J. Med. 305, 969.

Kotzin, B. L., Strober, S., Kansas, G. S., Terrell, C. P. \& Engleman, E. G. (1984) Suppression of pokeweed mitogen-stimulated immunoglobulin production in patients with rheumatoid arthritis after treatment with total lymphoid irradiation. J. Immunol. 132, 1049.

Kupfer, A., Swain, S. L. \& Singer, S. J. (1987) The specific direct interaction of helper T cells and antigen-presenting B cells. II. Reorientation of the microtube organizing center and reorganization of the membrane-associated cytoskeleton inside the bound helper T cells. J. Exp. Med. 165, 1565.

Lowry, R. P., Forbes, R. D., Carpenter, C. B., Gurley, K. E. \& Merrill, J. P. (1984) Immune reactivity and immunosuppressive intervention in experimental nephritis: II. Effect of total lymphoid irradiation on the course of two models of nephritis in the inbred rat. J. Immunol. 132, 1007.

Malone, D. G., Wahl, S. M., Tsokos, M., Cattel, H., Decker, J. L. \& Wilder, R. L. (1984) Immune function in severe active rheumatoid arthritis: a relationship between peripheral blood mononuclear cell proliferation to soluble antigens and synovial tissue immunohistologic characteristics. J. Clin. Invest. 74, 1174.

Mizel, S. B., Dayer, J.-M., Krane, S. M. \& Mergenhagen, S. E. (1981) Stimulation of rheumatoid synovial cell collagenase and prostaglandin production by partially purified lymphocyte-activating factor (interleukin 1). Proc. Natl. Acad. Sci. USA 78, 2474.

Munthe, E. \& Natvig, J. B. (1971) Characterization of IgG complexes in eluates from rheumatoid tissue. Clin. Exp. Immunol. 8, 249.

Najarian, J. S., Ferguson, R. M., Sutherland, D. E. R., Slavin, S., Kim, T., Kersey, J. \& Simmons, R. L. (1982) Fractionated total lymphoid irradiation as preparative immunosuppression in high risk renal transplantation: clinical and immunological studies. Ann. Surg. 196, 442.

Nardella, F. A., Dayer, J.-M., Roelke, M., Krane, S. M. \& Mannik, M. (1983) Selfassociating IgG rheumatoid factors stimulate monocytes to release prostaglandins and mononuclear cell factor that stimulates collagenase and prostaglandin by synovial cells. Rheumatol. Int. 3, 183.

O’Brien, R. L., Happ, M. P., Dallas, A., Palmer, E., Kubo, R. \& Born, W. K. (1989) Stimulation of a major subset of lymphocytes expressing $\mathrm{T}$ cell receptor gamma delta by an antigen derived from Mycobacterium tuberculosis. Cell 54 (4), 667.

Ottenhoff, T. H. M., Torres, P., Terencio De Las Aguas, J., Fernandez, R., van Eden, W., de Vries, R. P. \& Stanford, J. L. (1986) Evidence for an HLA-DR4-associated immuneresponse gene for mycobacterium tuberculosis. Lancet II, 310.

Paulus, H. E., Machleder, H. I., Levine, S., Yu, D. T. Y. \& MacDonald, N. S. (1977) Lymphocyte involvement in rheumatoid arthritis: studies during thoracic duct drainage. Arthritis Rheum. 20, 1249.

Res, P. C. M., Schaar, C. G., Breedveld, F. C., van Eden, W., van Embden, J. D. A., Cohen, I. R. \& de Vries, R. R. P. (1988) Synovial fluid T cell reactivity against 65 Kd heat shock protein of mycobacterial in early rheumatoid arthritis. Lancet II, 478. 
Sabharwal, U. K., Vaughan, J. H., Fong, S., Bennett, P. H., Carson, D. A. \& Curd, J. G. (1982) Activation of the classical pathway of complement by rheumatoid factors: assessment by radioimmunoassay for C4. Arthritis Rheum. 25, 161.

Schurman, D. J., Hirshman, H. P. \& Strober, S. (1981) Total Lymphoid and local joint irradiation in the treatment of adjuvant arthritis. Arthritis Rheum. 24, 38.

Sliwinski, A. J. \& Zvaifler, N. J. (1970) In vivo synthesis of IgG by the rheumatoid synovial membrane. J. Lab. Clin. Med. 76, 304.

Smily, J. D., Sachs, C. \& Ziff, M. (1968) In vitro synthesis of immunoglobulin by rheumatoid synovial membrane. J. Clin. Invest. 47, 624.

Stastny, P. (1978) Association of the B-cell alloantigen DR4 with rheumatoid arthritis. New Engl. J. Med. 298, 869.

Stastny, P., Ball, E. J., Dry, P. J. \& Nunez, G. (1983) The human immune response region (HLA-D) and disease susceptibility. Immunol. Rev. 70, 113.

Strober, S., Modry, D. L., Hoppe, R. T., Pennock, J. L., Bieber, C. P., Holm, B. I., Jamieson, S. W., Stinson, E. B., Schroder, J., Soumalainen, H. \& Kaplan, H. S. (1984) Induction of specific unresponsiveness to heart allografts in mongrel dogs treated with total lymphoid irradiation and anti-thymocyte globulin. J. Immunol. 132, 1013.

Strober, S., Slavin, S., Gottlieb, M., Zan-Bar, I., King, D. P., Hoppe, R. T., Fuks, Z., Grumet, F. C. \& Kaplan, H. S. (1979) Allograft tolerance after total lymphoid irradiation (TLI). Immunol. Rev. 46, 87.

Strober, S., Tanay, A., Field, E., Hoppe, R. T., Calin, A., Engleman, E. G., Kotzin, B., Brown, B. W. \& Kaplan, H. S. (1985) Efficacy of total lymphoid irradiation in intractable rheumatoid arthritis: a double-blind, randomized trial. Ann. Intern. Med. 102, 441.

Takihara, Y., Reimann, J., Michalopoulos, E, Ciccone, E., Moretta, L. \& Mak, T. W. (1989) Diversity and structure of human T cell receptor $\delta$ chain genes in peripheral blood $\gamma /$ $\delta$-bearing T lymphocytes. J. Exp. Med. 169, 393.

Tanay, A., Schiffman, G. \& Strober, S. (1986) Effects of total lymphoid irradiation on levels of serum antibodies in systemic lupus erythematosus and in rheumatoid arthritis. Arthritis Rheum. 29, 26.

Tanay, A. \& Strober, S. (1984a) Opposite effects of total lymphoid irradiation on T cell dependent and T cell independent antibody responses. J. Immunol. 132, 979.

Tanay, A., Strober, S., Logue, G. L. \& Schiffman, G. (1984b) Use of total lymphoid irradiation (TLI) in studies of the T cell-dependence of autoantibody production in rheumatoid arthritis. J. Immunol. 132, 1036.

Theofilopoulos, A. N., Balderas, R., Shawler, D. L. Izui, S., Kotzin, B. L., Strober, S. \& Dixon, F. J. (1980) Inhibition of T cell proliferation and SLE-like syndrome of MRL/ 1 mice by whole body or total lymphoid irradiation. J. Immunol. 125, 2137.

Trentham, D. E., Belli, J. A., Anderson, R. J., Buckley, J. A., Goetzl, E. J., David, J. R. \& Austen, K. F. (1981) Clinical and immunologic effects of fractionated total lymphoid irradiation in refractory rheumatoid arthritis. New Engl. J. Med. 305, 976.

Van Eden, W., Thole, J. E. R., van der Zee, R., Naardzij, A., van Embden, J. D. A., Hensen, E. J. \& Cohen, I. R. (1988) Cloning of the mycobacterial epitope recognized by $\mathrm{T}$ lymphocytes in adjuvant arthritis. Nature $331,171$.

Waer, M., Ang, K. K., van der Schueren, E. \& Vandeputte, M. (1984) Influence of radiation field and fractionation schedule of total lymphoid irradiation (TLI) on the induction of suppressor cells and stable chimerism after bone marrow transplantation in mice. J. Immunol. 132, 985.

Waer, M., Vanrenterghem, Y., Roels, L., Ang, K. K., Bouillon, R., Lerut, T., Gruwez, J., van der Schueren, E., Vandeputte, M. \& Michielsen, P. (1987) Immunological and clinical observations in diabetic kidney graft recipients pretreated with total lymphoid irradiation. Transplantation 43, 371 . 
Walker, C., Herzog, C. \& Rieber, P. (1989) Anti-CD4 antibody treatment of patients with rheumatoid arthrits. II. Effect of in vivo treatment on in vitro proliferative response of CD4 cells. J. Autoimmun. 2, 643.

Ward, J. R., Williams, H. J., Egger, M. J., Reading, J. C., Boyce, E., Altz-Smith, M., Samuelson, C. O. Jr, Willkens, R. F., Solsky, M. A., Hayes, S. P., Blocka, K. L. Weinstein, A., Meenan, R. F., Guttadauria, M., Kaplan, S. B. \& Klippel, J. (1983) Comparison of auranofin, gold sodium thiomalate, and placebo in the treatment of rheumatoid arthritis: a controlled clinical trial. Arthritis Rheum. 26, 1303.

Ward, P. A. \& Zvaifler, N. J. (1971) Complement-derived leukotactic factors in inflammatory synovial fluid of humans. J. Clin. Invest. 50, 606.

Weinblatt, M. E., Coblyn, J. S., Fraser, P. A. Anderson, R. J., Trentham, D. E. \& Austen, K. F. (1986) Cyclosporin A in refractory rheumatoid arthritis (abstract). Arthritis Rheum. (suppl) 29 (4), S79.

Wernick, R. M., Lipsky, P. E., Marban-Arcos, E., Maliakkal, J. J., Edelbaum, D. \& Ziff, M. (1985) IgG and IgM rheumatoid factor synthesis in rheumatoid synovial membrane cell cultures. Arthritis Rheum. 28, 742.

Young, C. L., Adamson, T. C. III, Vaughan, J. H. \& Fox, R. I. (1984) Immunohistologic characterization of synovial membrane lymphocytes in rheumatoid arthritis. Arthritis Rheum. 27, 32.

Zvaifler, N. J. (1973) The immunopathology of joint inflammation in rheumatoid arthritis. Adv. Immunol. 16, 265. 
This document is a scanned copy of a printed document. No warranty is given about the accuracy of the copy. Users should refer to the original published version of the material. 